\title{
Beyond opportunity structures: explaining migrant protest in Western Europe, 1975-2005
}

\author{
Oliver Strijbis
}

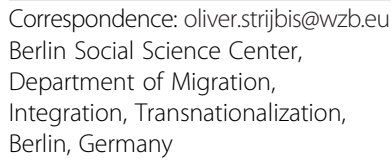

\begin{abstract}
The dominance of the political opportunity structure approach has led to an emphasis of institutional variables in the field of migrant mobilization. This paper critically discusses political opportunity structure theory and defends alternative explanations for variance in levels of ethnic protest among migrants. In particular, it is argued that cultural distance, social stratification, and transnational bonds might be the driving forces behind the political mobilization of migrants. The theories are tested with protest event data for seven European countries between 1975 and 2005.
\end{abstract}

Keywords: Migrants; Protest; Social movements; Political opportunity structures; Structuralism; Transnationalism

\section{Background}

Ethnic mobilization can manifest itself in parliamentary or extra-parliamentary politics. While ethnic minority mobilization is institutionalized in the political arena through ethnic parties, in the extra-parliamentary arena it is structured by ethnic social movements (Olzak, 2006, pp. 42-47). An important form of this mobilization is protest - a nonconventional form of political mobilization. This paper focuses on migrant protest, a subtype of ethnic protest denoting cases in which action taken by migrants remains congruent with their group boundaries. The goal is to explain when migrants protest takes place, i.e. when migrants use protest in order to mobilize for their specific political goals.

A first contribution this article makes is theoretical. We engage in a critical assessment of political opportunity structure theory (POS) - the dominant approach in the study of migrant mobilization. More specifically we distinguish between a broad and a narrow version of POS and discuss the theory against approaches emphasizing ethnic division of labor, cultural distance, and transnational bonds.

The second aim is to analyze a unique dataset on migrant protest. Since for the first time insights on levels of political mobilization over a considerable time period across several countries are analyzed, this study complements the empirical literature on migrants' political behavior in important ways. The empirical analysis points to limitations of political opportunity structure theory and provides evidence for the explanatory potential of alternative approaches.

The remainder of the article is organized as follows. Firstly, we give a short literature review and discuss strengths and shortcomings of POS. In the second chapter, we 
point to three alternative theories, which might be able to explain variance in the political mobilization of immigrants. Thirdly, we present the protest data for seven countries (Austria, France, Germany, the United Kingdom, the Netherlands, Spain, and Switzerland) between 1975 and 2005. Fourthly, we conduct quantitative multivariate analyses at the country and the group level. We conclude by reflecting the results of this analysis in the light of research on ethnic mobilization and discuss avenues for future research.

\section{Political opportunity structures and the political behavior of migrants}

The literature on the political behavior of migrants is growing quickly. In particular, three strands of research are worth mentioning. Firstly, the literature on political participation of migrants consists typically of survey analyses for a small number of migrant groups and investigates participation rates for all kinds of political activities (Fennema and Tillie, 2001; Fennema and Tillie, 1999; Klandermans, Van der Toorn, and Van Stekelenburg, 2008; Eggert and Giugni, 2010; Maxwell, 2010). The strong point of this literature is that it enables to test various kinds of theories at the microlevel. However, because the studies typically focus on a limited number of groups and time points, they are less suited for the analysis of variance at the macro-level. ${ }^{1}$ Furthermore, most of these studies are less interested in the content that is transported than in participation levels as such.

Secondly, this gap has partly been closed by the analysis of claims-making. The study of claims-making has generated important insights into the content of mobilization among migrant groups by analyzing the quality of the claims made in the field of citizenship politics. Hence, this literature has contributed considerably to the knowledge about migrants' political behavior in the extra-parliamentary arena (Statham, 1999; Koopmans et al., 2005; Giugni and Passy, 2004). However, due to issues of selection bias the analysis of claimsmaking has its limitations when it comes to the study of levels of mobilization.

Finally, studies on the electoral behavior of migrants have generated important insights into the political behavior of migrants in the parliamentary arena. It has, for instance, been shown that - with the important exception of migrants from Eastern Europe - migrants tend to vote and be represented (both in personal and ideological terms) by left political parties (Bird, Saalfeld, and Wüst, 2011; Messina, 2007; Schönwälder, 2009; Teney et al., 2010; Strijbis, 2014).

Several theories have been developed in order to understand variance in these different forms of migrants' political behavior (for an overview see Bird, Saalfeld, and Wüst, 2011, pp. 9-16). Ethnic identity theory basically states that ethnicity matters. It assumes that migrants hold strong ethnic identities, and emphasizes the relevance of this identity for their political behavior (e.g. Barreto, 2007). Ethnicity theory relates to the fact that ethnicity is often a good predictor for variance in the political behavior of migrants, and migrants' political mobilization is often framed along ethnic lines. Ethnicity theory, however, does not directly explain behavior. It tends to remain ambiguous in regard to the motivations for migrants' political behavior. For instance, do members of an ethnic group vote for co-ethnic candidates because they share the same political preferences or because they expect benefits for their community (or both)?

Social capital theory emphasizes the potential of social networks and mutual trust as a resource for political mobilization (Putnam, Leonardi, and Nanetti, 1994). There is 
broad consensus that 'bridging' social capital, i.e. access to diffused social networks and general trust in others, allows migrants participating in politics at higher rates (but see Alesina and Giuliano, 2011). What is debated, however, is whether 'bonding' social capital, i.e. access to exclusive social networks and trust in the same social group, also has positive effects on political participation at large. More specifically, in the context of migration studies the question is whether participation in ethnic organizations triggers political participation beyond the realm of the own ethnic group or whether it is counterproductive (Fennema and Tillie, 1999; Van Londen, Phalet, and Hagendoorn, 2007; Jacobs and Tillie, 2004; Jacobs, Phalet, and Swyngedouw, 2006). The weak points of social capital theory in general, and applied to migration research in particular, are twofold. First of all, the concept of social capital often remains somewhat ambiguous and hard to operationalize (Bjørnskov and Sønderskov, 2010). Empirically, this has been demonstrated by showing that different indicators for social capital such as membership in organizations and social trust are only weakly correlated. Secondly, social capital might rather be seen as a mediating variable, which explains why members from higher social strata are generally politically more active than those from lower classes, than as an independent variable in its own right.

In most Western countries migrants have occupied the economic positions of the working class. Furthermore, in terms of age, gender and residence, migrants have usually been overrepresented among the young, urban and male population. Sociodemographic explanations emphasize this young lower class character of the political mobilization of migrant groups. Often used for means of 'control', these sociodemographic variables are meant to capture that part of variation between natives and migrants that is not causally linked to a migration background. The fact that migrants might have good reasons to mobilize along categories that are more directly linked to migration such as ethnicity, religion, language, etc. is neglected by socio-demographic explanations. Consequently, socio-demographic explanations, if taken too far, become implausible since they entirely neglect the migration experience for the explanation of behavioral differences between natives and migrants. However, as a correction for approaches that tend to uncritically assume that other categories than socio-demographic ones are most relevant for native-migrant differences should always be taken into account.

The dominant theory of migrant political behavior today, however, is the political opportunity structure theory (POS). POS has been developed in the field of social movements in order to explain levels of mobilization as well as the action repertoire used across countries and movements. With the adoption of POS to many different contexts by a considerable number of scholars, POS has included a large number of variables that might structure the behavior course of social movements. This broader understanding of POS (henceforth 'broad POS') includes institutional elements such as state strength, societal elements such as the structure of political cleavages, the cleavages' translation into alliance structures, as well as strategies by the political authorities (Kriesi et al., 1995).

By including formal institutions and more societal variables such as cleavage structures among the explanatory variables, broad POS sets the political institutions on the same level of causality as societal factors. ${ }^{2}$ As a consequence, broad POS leaves us with a broad set of potential independent variables in order to explain political behavior, a 
fact that has inspired several of the most excellent analyses. This eclecticism, which makes no clear distinction between social structures and political institutions, however, comes at the cost of parsimony (also Hooghe, 2005, p. 978).

The authors that have adopted the theory to the explanation of migrant behavior seem to be conscious of this weakness of broad POS. In line with new institutionalist thinking, they have opted for a more narrow understanding of opportunity structures (henceforth called 'narrow POS'), and emphasize the political institutions at the expense of social structures. ${ }^{3}$ In particular, they have tried to show that through the adoption of citizenship regimes the nation-states still have an important impact on the political behavior of the actors in the migration field (Ireland, 1994; Koopmans, et al., 2005; Giugni and Passy, 2004; Morales and Giugni, 2011). By using the term "citizenship regimes", Koopmans et al., (2005) refer, on the one hand, to individual access to nationality and, on the other hand, to cultural group rights. According to them, these institutions structure political behavior of migrants in two ways.

First, they provide strategic incentives for deciding whether claims should be made and in what form. Typically, it is expected that political opportunity structures trigger the political mobilization of migrants. Koopmans, (2004), for instance, explains the degree to which immigrants participate in public debates concerning them with the inclusiveness of local incorporation regimes. Similarly, Cinalli and Giugni, (2013), argue that individual and group rights trigger collective action by Muslims.

Second, citizenship regimes have an impact on the collective identities of the migrants and the framing of their claims. Political opportunity structures, for instance, are assumed to be decisive for migrants' choices on whether to make claims along the categories of 'migrants', 'foreigners' or 'national and ethnic minorities'. Hence, it could also be argued that while open citizenship regimes trigger some forms of political mobilization they negatively impact on migrant protest among which protest along migrant group boundaries. In this sense it is not entirely clear in which direction citizenship regimes impact on migrant protest according to the theory. What is clear, however, is that narrow POS expects citizenship regimes to have some impact on migrant protest.

Despite its impressive success in explaining patterns of claim-making in the field of citizenship politics, including migrant minorities, narrow POS suffers from two important weaknesses. First, POS can hardly explain commonalities in levels of mobilization of the same ethnic group in different countries. It can, for instance, not explain why Turkish migrants mobilize strongly in various European countries independently of the institutional context (Strijbis, 2011).

Second, it can hardly explain dissimilarities among different migrant groups within a country. With the exception of migrants from EU-countries and/or former colonies, citizenship regimes do apply in the same way to most migrant groups. In order to explain variance between groups within the same country, POS therefore needs to be combined with factors that are more specific to the groups. Koopmans et al., (2005) consequently add a transnationalist approach to POS theory in order to explain patterns of claim-making among migrants.

Another attempt to combine POS with a theory that is more capable of explaining group differences within the same countries has been undertaken by Statham, (1999). He explains differences between the mobilization of African-Caribbeans and minorities from the Indian subcontinent by different opportunity structures, but explains variance 
between different religious groups amongst the Asian migrants by referring to different socio-economic positions.

\section{Alternative explanations: ethnic division of labor, cultural distance, and transnationalism}

In political economy, scholars have answered to the same critique raised in the previous chapter on narrow POS by focusing on economic structures (e.g. Boix and Stokes, 2003; Przeworski, 1991; Rogowski and MacRae, 2004; Ticchi and Vindigni, 2003). As is well known, according to economic structuralism, it is the individual's position in the system of social stratification that determines his or her political preferences. In the realm of migrant mobilization, for instance, economic structuralism has interpreted social movements that are formed by an alliance of migrants and natives, such as the anti-racism movement, as a mobilization of common class interests (Ireland 1994, p. 234). This might seem plausible at a first glance because in most Western countries migrants have been overrepresented among the working class.

The problem of such an interpretation, however, is that migrants' mobilization along ethnic lines has to be interpreted as being caused by a lack of class-consciousness (Connor 1994, p. 149). Thus, if economic structuralism should be able to explain variance in the political mobilization of migrant groups, it needs to incorporate some notion of ethnic group boundaries. In interaction with ethnic group boundaries, economic differences can, however, result in an ethnic division of labor, and constitute as such an important structural basis for political mobilization (Hechter and Levi, 1979). According to this classical ethnic division of labor theory mobilization along ethnic group lines should happen if they are concentrated in specific economic sectors (segmental division) or strata (hierarchical division). The reason is that ethnic concentration in different social strata and segments leads to fewer interethnic contacts and comes with diverging political interests. This makes the formation of interethnic political alliances difficult with the result that migrant groups mobilize for themselves. In contrast, these low levels of social interaction with mainstream society lead to a higher capacity for group mobilization (Maxwell 2012, p. 4). Hence, according to this line of reasoning we can expect migrant protest to be the stronger the more occupationally concentrated migrants are.

But not only economic disparities can be understood as a structural force (Sewell Jr., 1992). Cultural distance along ethnic group boundaries also can. By using the term 'cultural distance', we refer to the access to different symbol systems, in which different norms and values are hegemonic. The mechanisms of reproduction of a symbol system remain relatively stable over time (Wimmer 2002; Bourdieu, 1990). ${ }^{4}$ We do not mean to neglect that migrants gradually absorb much of the host culture, as assimilation theories suggest, but to acknowledge that these are typically rather time-consuming processes (Norris and Inglehart, 2012).

As with economic division of labor, in the case of cultural distance political entrepreneurs will hardly find a common denominator large enough to mobilize migrants and natives jointly. In Europe, probably the largest coalition of this kind was formed in the anti-racist movement. The power of this movement was rendered possible by the existence of strong preferences for the just treatment of migrants also among large segments of the native society. However, high levels cultural distance makes these commonalities in political preferences unlikely and so doing hinders migrant-native 
alliances. Since migrant protest only refers to mobilizing along the lines of the migrant communities we can therefore hypothesize that the more distinct the migrants are from the natives in cultural terms, the more they will engage in protest along their group boundaries.

What makes the mobilization by migrants different from other forms of ethnic mobilization is that migrants can be politically involved in both the sending and the receiving country. Increasingly, globalization allows migrants to form transnational communities and share multiple identities (Castles, 2002). Receiving countries often promote these transnational bonds with the goal of stimulating remittances from the expatriates (Portes and Rumbaut, 2006). This implies that migrants remain connected to their sending state and are therefore also expected to mobilize in the case of political conflict in their country of emigration. In fact, many migrants leave for political reasons such as war or discrimination in the sending state. In the context of a globalized world, in which migrants can easily remain informed about the political situation in the sending state and might even be in continuous contact with family members that remained there, opposition to the government in the sending state is a strong source of motivation. Hence, we can assume that more migrants protest in the case of war or discrimination in the sending state.

\section{Methods}

The empirical analysis of political mobilization by migrant groups has remained difficult due to a lack of data. So far comparative research has made use especially of two types of sources. First, most researchers have used surveys that include questions on various types of political participation. The strength of the surveys is that they avoid problems of ecological fallacy and can be used to analyze a broad range of participation forms. Among the weaknesses are problems in achieving representative samples for specific migrant groups, overestimation of political participation, and usually a lack of time series data. The last point might have the effect of data being strongly biased by contextual events. This is not a problem for questions concerning the electoral behavior of migrants, but for extra-parliamentary mobilization which is not restricted to specific points in time.

Second, researchers have analyzed claims reported in the media. Such an approach has the important advantage that it measures behavior in the extra-parliamentary channel and provides time series data. A major strength of this approach is that it gives qualitative information on the claims that are made. Koopmans et al., (2005) have made heavy use of this qualitative information in order to test their theory. In relation to the mobilization of immigrants, they have exploited the distinction between claims that refer to the sending and those that relate to the receiving country. However, the coding of this information has been criticized as being invalid. For the Dutch data, Mügge, (2012) has shown that the coding in the claim making data heavily overestimates the number of claims made towards the receiving state. The main pitfall of this analysis, however, lies in the fact that the data was not collected to measure levels of mobilization. The broadening of the unit of analysis, in combination with the application of a sampling method, has the effect that only a rather small sample of the protest events are covered (Hutter, 2011). 


\section{Protest event data}

A more valuable data set for the analysis of levels of extra-parliamentary mobilization by migrants consists of information on protest events (similarly Ebert and Okamoto, 2013). This kind of data, which has been gathered in two large waves, contains systematic information on all kinds of protest events, and covers all Monday issues from quality newspapers (Kriesi et al., 1995; Hutter and Giugni 2009; Hutter 2011; Strijbis, 2014). For this study the data is available for seven European countries (Austria, France, Germany, the Netherlands, Switzerland, Spain and the United Kingdom). The decision whether an event is classified as a protest is based on a detailed list of actions that are considered to be a form of protest. It includes petitions, political festivals, mass demonstrations, hunger strikes, occupations and violent attacks.

The newspapers included are Die Presse, Le Monde, Frankfurter Allgemeine Zeitung, The Guardian, NRC Handelsblad, Neue Zürcher Zeitung and El País. These newspapers were chosen because of their continuous and daily publication. They are expected to report on protest events with a similar kind of selectivity, and cover the entire national territory (Koopmans 1995, pp. 255-256). While the data is available for six countries from 1975 to 2005, the data for Spain covers the period from 1996 to 2005. Taken together, 196 country-years of protest events are covered.

A major potential weakness of the PEA data used here is that it can be exposed to selection bias (Fillieule 1996; Hug and Wisler, 1998; Hocke, 2002; Hug, 2003). ${ }^{5}$ Selection bias can emerge when the selected cases (here the protest events) are not part of a random sample and do not cover the entire population. Selection bias in the PEA dataset can be the result of selecting Monday issues 'only' and the fact that national newspapers do not cover all protest events. According to some scholars, the potential bias that is generated by this imperfect data generation process is so severe that this kind of data hardly allows for valid inferences (Ortiz et al., 2005).

The problems of selection bias are, however, less severe than often assumed, and surmountable for this study. As Hutter, (2011, p. 133) shows, the selection of Monday issues does not lead to selection bias when the number of protestors is taken as an indicator. In the case of this analysis, the selection bias due to the choice of Monday issues seems to be even less concerning. This is because the migrant protests tend to take place on weekends, which leads to particularly high coverage rates (Barranco and Wisler, 1999; Hutter, 2011). Additionally, using the number of protestors as an indicator still reduces the bias because large protest events that take place during the week tend to be mentioned in the ensuing Monday editions as well.

Selection bias might also occur because national newspapers choose to report on some protest events while neglecting others due to features of the protest. Again, relying on the number of protestors as an indicator strongly reduces the selection bias because large protests tend to be covered. Thus, this bias remains, but it is rather small and systematic and does, therefore, hardly affect cross-country comparisons (Hutter, 2011, pp. 139-140).

There is one major exception to the systematic nature of the selection bias in the PEA data. As the comparison of coverage based on Reuters news reports and national newspapers suggests, the selection bias for the Austrian data is larger than for the other cases (Hutter, 2011, p. 144). ${ }^{6}$ 


\section{Results and discussion}

Figure 1 depicts the levels of migrant protest mobilization as a ratio of the national population and the number of foreign-born in the seven countries under study between 1975 and 2005. The data shows strong variation in protest levels both between countries and over time. While in Austria, France, the Netherlands and the UK levels of protest mobilization have remained rather stable over time, in Germany, Spain and Switzerland the levels increased more or less steadily. Regarding the overall levels of mobilization, one can observe that the levels of mobilization (relative to the share of the number of migrants) are higher in the Netherlands, Germany and Switzerland than in the other four countries.

Because historical comparative analysis of migrant behavior suffers from considerable data restraints, testing causal relations is not an easy task. What makes empirical analysis in this field particularly demanding is that the data on migrants suffers from the fact that national authorities have only recently begun to make use of categories that mirror a meaningful operationalization of migration status (Jacobs et al., 2009). Data on foreigners has often been used to approach facts that concern migrants. As has regularly been remarked, however, such data is of little use in comparative studies on migrants. This empirical test, therefore, makes use of data on foreign-born residents whenever possible.

While the reliance on data on foreign-born residents is the most adequate operationalization of immigration status, it severely limits the availability of data in terms of both time and subject. Consequently, we conduct two types of analyses with different strengths and weaknesses. First, we conduct a time-series cross sectional analysis of migrant protest at the national level. This analysis is conducted with data for seven countries between 1975 and 2005, and allows us to test explanations for variance in migrant

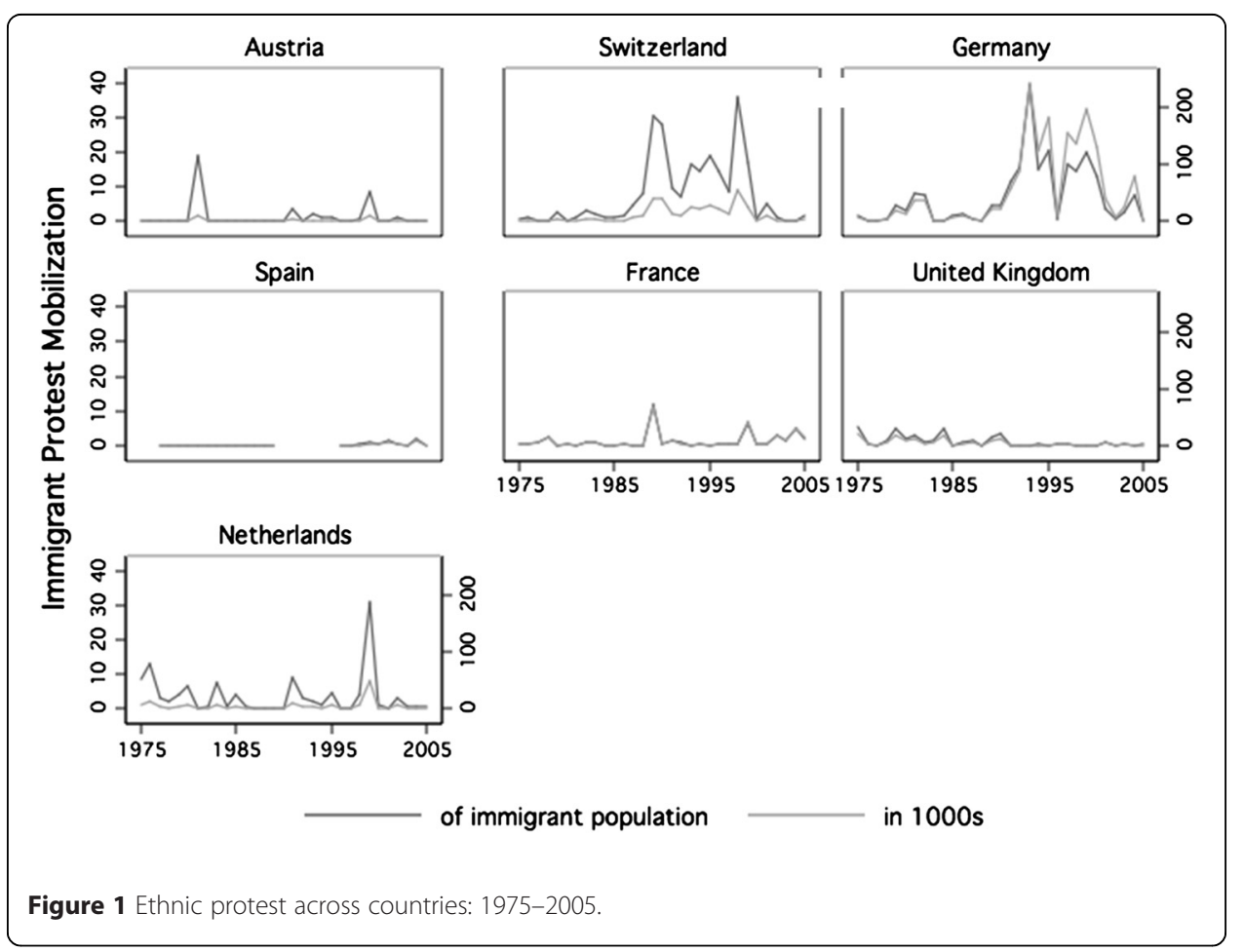


protest across time. The weak points are that we cannot make distinctions along ethnic and national group lines, and that we therefore have to make use of rather crude proxies for the operationalization of some of our independent variables. While the former may lead to aggregation problems with the result that effects at the group level are under- or overestimated at the level of all migrants the latter might lead to measurement error.

Second, we conduct a cross-sectional analysis along the national group line. Since it was only possible to code the protest events per national group when the data entry included a 'core sentence', the data is only available for the 1996-2005 period. ${ }^{7}$ Having recoded all core sentences of migrant protest events for the seven countries during this time period, it was possible to construct a dummy variable for the presence of migrant protest for each sending state between 1996 and 2005. Merging this information with data for the independent variables resulted in a sample of 288 groups. The strong point of this analysis is that we can lower the level of aggregation and investigate within country variance across groups in a considerable number of cases. Its weak point is that it does not allow analyzing variance over time. In sum, the two types of analyses complement each other very well.

\section{Ethnic protest across countries: 1975-2005}

Let us turn to the time-series cross-section analysis first. As was explained above, the dependent variable is the estimated number of protestors as reported in Monday newspapers. In order to measure the preconditions of migrant protest, i.e. war or discrimination in the sending state, we include the number of asylum seekers as an independent variable. This is a good indicator because war or discrimination in the sending state is a formal condition for the granting of asylum status. Also war and discrimination are strong predictors for the flows of asylum seekers (Neumayer, 2005). Finally, for the time-series analysis the number of asylum seekers is the best available indicator for the number of immigrants that migrated due to political reasons. This is because data on the number of migrants according to their country of birth - which would be necessary to estimate the share of immigrants that migrated due to war or discrimination in their sending state based on other sources - are not available for the whole period under analysis.

The other independent variables are operationalized as follows. In order to measure cultural distance we rely on two different indicators. First, we construct a variable for linguistic distance where we count the share of foreigners from a country with only different national languages as the receiving country. We rely here on studies showing that linguistic distance is related with distance in norms and values (e.g. Licht, Goldschmidt, and Schwartz, 2007). Unfortunately this data is not available for the entire time series according to country of birth. Hence, the data has been estimated according to information of the citizenship of the foreign residents. In this case only data from 1975 to 1985 for the UK and 1997 for Spain remains unavailable. We also measure a variable for religious distance with the share of the Muslim population per country. We restrict ourselves to the Muslim population because in Western Europe it is by far the largest religion to which only few natives adhere. Among those it is also the only for which data has been systematically collected for the time period under investigation. However, not all countries have 
reliable official data on the denomination of its population (Brown, 2000). Hence, if there was no official data on the number of Muslims in a country, we made use of the estimates of Kettani, (1986) for 1982, and the Pew Research Centre (Grim and Karim, 2011) for 1990, 2000 and 2010. ${ }^{8}$

Additionally we add a variable for the share of postcolonial migrants among all migrants. We apply a narrow definition of former colonies by including among those only countries that have become independent after 1945 . Here we can rely on the share of foreign born (instead of foreigners) since for the formerly colonial countries this data exists. Relying on data on foreign born is particularly important here because migrants from former colonies had sometimes easy access to nationality. On the one hand this is an additional indicator for cultural distance since due to strong historical relationships cultural interaction remained stronger between colonial states and their former dependencies. According to this interpretation larger shares of postcolonial migrants should be related with lower levels of protest. On the other hand postcolonial migrants might also be confronted with different political opportunity structures than other migrants and their claims could be of higher legitimacy in the receiving state. In this case we would expect higher shares of postcolonial migrants to be positively related with protest mobilization by migrants.

In order to measure ethnic division of labor we calculate the share of the migrants employed in the industrial sector relative to the overall share of industry workers. Here we apply a broad definition including workers in the construction sector. ${ }^{9}$ Since data on foreign born is not available for the entire time period we calculate this indicator with data on foreigners.

As a means of control for the influence of political opportunity structures (as per a narrow understanding), we include Koopmans et al.'s, (2012) measure for cultural group and individual rights. The data is available for 1980, 1990, 2002 and 2008. For this variable data on Spain is not available. Additionally, we control for the number of participants in strikes and the estimated number of protest participants in all protests. While the former is the best indicator to measure extra-parliamentary mobilization by the worker's movement, the latter is the ideal indicator to measure levels of extra-parliamentary mobilization by all other social movements.

For all variables the data was interpolated if necessary. If fewer than five data points were missing the data was also extrapolated. However, this has not been done for the political opportunity structure variables, the participants in strikes, and the protest participants since values on these variables did not follow clear time trends. In order to check whether the independent variables are merely measuring time trends or to country differences that could potentially be correlated to many variables, we introduce a trend variable and country dummies. Note that the latter also works as a robustness check for potential selection bias in the Austrian case.

Table 1 summarizes the data for all indicators. The cases are restricted to those 181 country-years for which data on our independent variables are available. The summary shows, for instance, that the mean number of participants in migrant protests, as reported in Monday issues of national newspapers, is over 13,500 per year. Therefore, participants in migrant protests make up around 2 per cent of the approximately 640,000 protest participants that are counted in an average year. Table 1 also reveals 
Table 1 Summary of descriptive statistics for country-level data, 1975-2005

\begin{tabular}{llllll}
\hline Variable & $\mathbf{N}$ & Mean & Std. dev. & Minimum & Maximum \\
\hline Immigrant protest participants (1000s) & 181 & 13.51 & 35.03 & 0.00 & 243.61 \\
Asylum seekers (1000s) & 181 & 35.11 & 51.01 & 0.47 & 438.19 \\
Share muslim population & 181 & 0.03 & 0.02 & 0.01 & 0.08 \\
Share linguistically distinct & 181 & 0.72 & 0.25 & 0.19 & 0.99 \\
Share postcolonial migrants & 181 & 0.22 & 0.25 & 0.00 & 0.62 \\
Share foreign borns in industry (rel.) & 181 & 0.12 & 0.11 & -0.09 & 0.40 \\
Foreign borns (mio.) & 181 & 3.34 & 2.68 & 0.30 & 10.66 \\
Strike participants (1000s) & 180 & 187.69 & 464.57 & 0.00 & 4534.27 \\
All protest participants (1000s) & 175 & 638.59 & 993.20 & 0.75 & 7181.43 \\
Collective rights & 151 & -0.15 & 0.35 & -0.55 & 0.52 \\
Individual rights & 151 & -0.11 & 0.40 & -0.69 & 0.54 \\
\hline
\end{tabular}

Sources: Central Bureau for Statistics of the Netherlands; German Microcensus; International Labour Organization (ILO); International Migration Outlooks (SOPEMI); National Statistics Institute of Spain; Koopmans et al. 2012; Kriesi et al. 1995; Pew Research Center; Rendall \& Salt 2006; Safi 2006; Strijbis 2014; Swiss Statistical Office.

that data was not available for all control variables for all time points. Data on group and individual rights is missing for the pre- 1980 period and for all time points in the case of Spain. Data on overall protest levels is missing for Spain since 1996, and the data on the strike participants misses one case.

A closer look at the summary statistics of the dependent variable of the country-level data reveals that the estimated number of participants in migrant protests does not come close to a normal distribution. Instead, the large number of years in which no migrant protest has been observed at all in the longitudinal data, and the large number of ethnic groups without protest in the cross-sectional data produces strongly skewed distributions. The data comes fairly close to a binomial distribution. Consequently, it makes sense to estimate binomial regressions in order to estimate the effects of independent variables on the number of migrant protest participants. The fact that longitudinal data is analyzed also raises the question whether the errors are auto-correlated. The inspection of the data in the correlograms, however, reveals that auto-correlation is not an issue here.

The results of the regression analysis are presented in Table 2. Model 1 shows the results for the independent variables and the share of foreign born. The share of asylum seekers is, as expected, positively and significantly correlated with migrant protest. This indicates that immigrant protest is indeed associated with political instability and repression in the sending state. Also the share of the Muslim population is positively related with immigrant protest. The coefficient, however, remains statistically insignificant. The share of linguistically distinct migrants, on the other hand, points into the opposite direction of what was expected, and remains statistically insignificant. It should be noted, however, that this negative relationship would be changed into a positive one (though still insignificant) if the Italian migrants in Switzerland would be considered as linguistically distinct, which is true for those Italian migrants that reside in the German speaking part of the country. Nevertheless, it can be concluded that the hypothesis that culturally more distinct migrants protest more along group boundaries is not supported in this analysis. 
Table 2 Binomial regression analysis for migrant protest participants (in 1000s)

\begin{tabular}{|c|c|c|c|c|c|}
\hline & Model 1 & Model 2 & Model 3 & Model 4 & Model 5 \\
\hline \multirow[t]{2}{*}{ Asylum seekers } & $0.0210^{* * *}$ & $0.0127^{* *}$ & $0.0106^{* *}$ & $0.0125^{* *}$ & $0.00944^{*}$ \\
\hline & $(4.34)$ & $(2.76)$ & $(2.79)$ & $(2.78)$ & $(2.36)$ \\
\hline \multirow[t]{2}{*}{ Share Muslims } & $23.70^{*}$ & -5.735 & 18.87 & 10.76 & 10.66 \\
\hline & $(2.48)$ & $(-0.45)$ & $(1.34)$ & $(1.04)$ & $(0.81)$ \\
\hline \multirow[t]{2}{*}{ Share linguistically distinct } & -0.322 & -0.953 & -1.336 & -0.521 & -1.555 \\
\hline & $(-0.58)$ & $(-1.67)$ & $(-0.51)$ & $(-0.89)$ & $(-1.13)$ \\
\hline \multirow[t]{2}{*}{ Share postcolonial migrants } & $-1.674^{* *}$ & -0.620 & -1.849 & $-1.333^{*}$ & $-4.508^{* *}$ \\
\hline & $(-2.96)$ & $(-0.95)$ & $(-0.45)$ & $(-2.19)$ & $(-2.98)$ \\
\hline \multirow[t]{2}{*}{ Share foreigners in industry (rel.) } & 1.166 & $6.809^{* *}$ & 0.416 & 1.866 & $7.084^{*}$ \\
\hline & $(0.88)$ & $(2.85)$ & $(0.16)$ & $(1.29)$ & $(2.07)$ \\
\hline \multirow[t]{2}{*}{ Foreign-borns (mio.) } & & $0.161^{* *}$ & 0.274 & $0.187^{*}$ & $0.159^{*}$ \\
\hline & & $(2.93)$ & $(1.91)$ & $(2.55)$ & $(2.21)$ \\
\hline \multirow[t]{2}{*}{ Trend } & & $0.0793^{*}$ & & & \\
\hline & & $(2.50)$ & & & \\
\hline \multirow[t]{2}{*}{ Austria } & & & -0.911 & & \\
\hline & & & $(-0.70)$ & & \\
\hline \multirow[t]{2}{*}{ Switzerland } & & & 0.702 & & \\
\hline & & & $(0.40)$ & & \\
\hline \multirow[t]{2}{*}{ France } & & & -0.910 & & \\
\hline & & & $(-0.48)$ & & \\
\hline \multirow[t]{2}{*}{ Great Britain } & & & -0.945 & & \\
\hline & & & $(-0.27)$ & & \\
\hline \multirow[t]{2}{*}{ Netherlands } & & & 1.317 & & \\
\hline & & & $(0.52)$ & & \\
\hline \multirow[t]{2}{*}{ Spain } & & & -1.118 & & \\
\hline & & & $(-0.76)$ & & \\
\hline \multirow[t]{2}{*}{ All protest participants (1000s) } & & & & -0.000103 & \\
\hline & & & & $(-0.52)$ & \\
\hline \multirow[t]{2}{*}{ Strike participants (1000s) } & & & & -0.000665 & \\
\hline & & & & $(-1.42)$ & \\
\hline \multirow[t]{2}{*}{ Collective rights } & & & & & 0.800 \\
\hline & & & & & $(0.57)$ \\
\hline \multirow[t]{2}{*}{ Individual rights } & & & & & 1.487 \\
\hline & & & & & $(1.11)$ \\
\hline \multirow[t]{2}{*}{ Constant } & 0.830 & $-156.8^{*}$ & 1.114 & $1.047^{*}$ & $2.394^{* *}$ \\
\hline & $(1.84)$ & $(-2.48)$ & $(0.34)$ & $(2.17)$ & $(2.85)$ \\
\hline \multirow[t]{2}{*}{ Ln alpha constant } & $0.879 * * *$ & $0.809^{* * *}$ & $0.581^{* * *}$ & $0.839^{* * *}$ & $0.807^{* * *}$ \\
\hline & $(7.64)$ & $(6.90)$ & $(4.63)$ & $(7.03)$ & $(6.38)$ \\
\hline $\mathrm{N}$ & 181 & 181 & 181 & 174 & 151 \\
\hline $\mathrm{AlC}$ & 1035.6 & 1028.0 & 1003.1 & 1004.7 & 901.5 \\
\hline $\mathrm{BIC}$ & 1058.0 & 1056.8 & 1047.9 & 1036.3 & 931.7 \\
\hline
\end{tabular}

t-statistics in brackets; ${ }^{*} p<0.05,{ }^{* *} p<0.01,{ }^{* * *} p<0.001$. 
For the share of postcolonial migrants and migrant protest a negative relation is shown. While this statistical relationships lends support to the interpretation that migrants from former colonies protest less often along group boundaries because they form alliances with natives, it goes against the expectation typically made by POS theory that postcolonial migrants would protest more because of their better political opportunities relative to other migrants. Furthermore, a higher share of migrants in the industrial sector seems to be positively related with migrant protest, which lends support to the division of labor hypothesis. However, without control for the time trend the coefficient remains insignificant (see below). Finally, unsurprisingly the more participants in migrants protest can be observed, the more migrants reside in a country.

Models 2 and 3 show the relationships between our set of individual variables and the dependent variable with a trend variable and country dummies respectively. The model with the trend variable allows to test whether our dependent variables predict variance in protest mobilization over time alone. If this were the case, it could indicate that the relationship between our set of independent variables and the dependent one was spurious because of an overall time trend in the data. As Model 2 shows, however, this is not the case for the number of asylum seekers. It could, however, be the case for the share of migrants from former colonies. Although the beta-coefficient for this variable remains negative it is not significant anymore. This does not mean that the variable is not related to migrant protest, but that more tests have to be undertaken in order to exclude a spurious relationship. Furthermore, the coefficient for the share of foreigners occupied in the industry is positively related to migrant protest now. This reveals that if this variable can explain variance in migrant protest it only predicts crosssectional variance. Finally, this model shows that the share of foreign born is able to predict variance in migrant protest across countries and that part of the positive trend in migrant protest has not been explained by our independent variables.

In Model 3, we test whether the data primarily predicts variance across countries. This would be problematic insofar as it would reveal that our independent variables show more (general) dissimilarity across countries that is not directly related to our theory and hence could indicate spurious relationships. This does not seem to be true for the number of asylum seekers since they remain largely unchanged once country dummies are introduced. It might, however, be a real issue for the other independent variables that have shown significant coefficients in the previous models. Although the direction of the statistical relations remains unchanged in these cases, they lose their statistical significance. The country dummies are also a robustness check for whether the results are biased by variance in the selectiveness of the different national newspapers, such as could be expected for Austria. Again, at least with regard to the relationship between the number of asylum seekers and migrant protest this is not the case.

In Model 4, control variables for the overall levels of protest mobilization and the number of strike participants are introduced. The data is not available for Spain, which explains the considerable decrease in the number of cases. Nevertheless, the results remain stable and show that migrant protest is not statistically related with overall levels of protest and strike activity.

In Model 5, we introduce the indicators for the migrants' collective and individual citizenship rights. This again reduces the number of cases since there is neither data for Spain nor the pre-1980 period for the other countries. The coefficients for both 
collective and individual rights for migrants are both insignificant. This suggests that political opportunity structures, at least as they are understood according to narrow POS, remain unrelated to immigrant protest. Again, despite the decline in the number of cases the coefficients for the other variables remain largely unchanged.

The results from the multivariate analysis allow three conclusions. First, the number of inflowing asylum seekers is a strong predictor of migrant protests both across time and space. This result follows the transnational logic. Second, citizenship rights have not proven to be important predictors of migrant protest. Considering the dominance of political opportunity structure theory (POS) in the field of migrant mobilization, and the prominent position of citizenship rights among these theories, this is a surprising result. It supports the theoretical argument from the first section, which holds that POS theory is confronted with considerable limits and might not be able to explain variance in migrant mobilization across time. Third, the results for our variables on cultural distance and economic division of labor remain unstable. In particular when country dummies are entered into the model the coefficients and their signficance changes considerably. One reason might be that for these variables problematic aggregation effects take place when all migrants are treated as one homogenous group. Also, by controlling for all cross-sectional variance the inclusion of country dummies is overly conservative and does therefore not allow to reject hypotheses. This suggests that we must disaggregate the country-level data in order to judge whether cultural distance, economic division of labor, and migrant protest are causally related to each other.

\section{Ethnic protest across groups: $1996-2005$}

The times-series cross-sectional analysis has provided a first test of POS and the alternative theories of migrant protest. However, it remains an open question whether cultural distance and the ethnic division of labor and migrant protest are systematically related to each other. In order to provide a better empirical analysis for cross-sectional variance, we conducted a cross-sectional analysis at the ethnic group level as described in a previous section. The dependent variable measures whether an immigrant group protested in at least one instance. The data relate to the years between 1996 and $2005^{10}$.

The independent variables are the same as in the cross-sectional times series analysis (see Table 3). The operationalizations can now take place at the group level and are therefore more precise. In order to measure linguistic distance, for instance, we can now make use of a dummy indicating whether one of the official languages of the receiving state is an official language in the sending state. For religious distance, we used a dummy indicating whether the majority population in the sending state is of Muslim denomination or not. Also for migrants from former colonies a dummy variable was used. The concentration of the migrants in the industrial sector was now calculated on the basis of the country of birth (instead of nationality). We also added a control variable for group size, measured as the number of foreign born by country of origin, and the share of unemployed.

The cross-sectional analysis also allows us to test whether the result that migrant protest is strongly conditioned by war or discrimination in the sending state is 
Table 3 Summary of descriptive statistics for group level data

\begin{tabular}{llllll}
\hline Variable & $\mathbf{N}$ & Mean/Ratio & Std. dev. & Min & Max \\
\hline Presence of protest & 288 & 0.087 & 0.282 & 0 & 1 \\
Asylum seekers (1000s) & 288 & 0.547 & 1.194 & 0 & 7.689 \\
Autocracy or ethnic war & 288 & 0.497 & 0.501 & 0 & 1 \\
Muslim & 288 & 0.274 & 0.446 & 0 & 1 \\
Other language & 288 & 0.740 & 0.440 & 0 & 1 \\
Postcolonial & 288 & 0.198 & 0.399 & 0 & 1 \\
Share in industry & 288 & 0.181 & 0.088 & 0.061 & 0.516 \\
Group size (1000s) & 288 & 54.271 & 147.723 & 0.179 & 1210.557 \\
Unemployed (1000s) & 288 & 4.925 & 16.467 & 0.014 & 149.24 \\
Individual rights & $273^{*}$ & 0.128 & 0.327 & -0.34 & 0.54 \\
Collective rights & $273^{*}$ & -0.094 & 0.366 & 0.457 & 0.341 \\
\hline
\end{tabular}

Notes: *Constant per country; Sources: International Migration Outlooks (SOPEMI); Koopmans et al. 2012; Kriesi et al. 1995; Pew Research Center; Rendall \& Salt 2006; Safi 2006; Strijbis 2014.

dependent upon latter's operationalization. ${ }^{11}$ Hence, in addition to measure war or discrimination in the sending state with the number of asylum seekers we make use of information on the political situation in the sending state. We make use of Polity IV scores in order to measure whether the sending state was an autocracy or not. The Polity IV project measures political regime characteristics on a global scale and over time (Marshall and Jaggers, 2002). We make use of the Polity 2 index, where a negative score indicates that the country was an autocracy. A major weakness of the Polity IV score is that it does not sufficiently take into account that specific minorities might be discriminated even if the regime as a whole cannot be considered an autocracy. Hence, we also code states as being at war or discriminating a share of its population if they are engaged in an ethnic war. ${ }^{12}$ We take this information from the Ethnic War Dataset (Cederman, Wimmer, and Min, 2010). Our resulting indicator is positively correlated with the share of asylum seekers $(\mathrm{R}=0.26 ; \mathrm{Pr}=0.00 ; \mathrm{N}=288)$-our original measure for war or discrimination in the sending state.

Model 1 shows the results for the independent variables with the inclusion of a variable for group size while model 2 includes country dummies, and model 3 includes values for individual and collective citizenship rights (see Table 4). All models show a positive relationship between the number of asylum seekers and the propensity to protest. This result is perfectly in line with the time-series cross sectional analysis.

The analysis also shows that for the most recent time period and at the group level religious distinctiveness is positively related with immigrant protest. Hence, this result also replicates the analysis of the time-series cross sectional analysis with the difference that in this model the relationship is also statistically significant. The difference between the two results can probably be attributed to the fact that only in recent time periods migrants with Muslim background make up a relevant share of all migrants. The result reveals that cultural distance does have a positive impact on migrant protest if culture is conceptualized in close relation with religion. In contrast, both linguistic distance and colonial history are not related to the propensity to protest. While the former result is in line with all models of the time-series cross-sectional analysis (see Table 2), the latter result is only in line with the more conservative models in 
Table 4 Logistic regression for presence of migrant protest at the group level

\begin{tabular}{|c|c|c|c|}
\hline & Model 1 & Model 2 & Model 3 \\
\hline \multirow[t]{2}{*}{ Asylum seekers } & $0.361^{*}$ & $0.707^{* * *}$ & $0.530^{* *}$ \\
\hline & $(2.52)$ & $(3.38)$ & $(3.06)$ \\
\hline \multirow[t]{2}{*}{ Share Muslims } & $1.493^{* *}$ & $1.444^{* *}$ & $1.628^{* *}$ \\
\hline & $(2.93)$ & $(2.64)$ & $(3.01)$ \\
\hline \multirow[t]{2}{*}{ Share linguistically distinct } & -0.758 & 0.0579 & -0.0967 \\
\hline & $(-1.16)$ & $(0.08)$ & $(-0.13)$ \\
\hline \multirow[t]{2}{*}{ Share postcolonial migrants } & -0.428 & 0.546 & -0.150 \\
\hline & $(-0.57)$ & $(0.62)$ & $(-0.17)$ \\
\hline \multirow[t]{2}{*}{ Share foreigners in industry (rel.) } & $6.544^{*}$ & 4.504 & 4.249 \\
\hline & $(2.41)$ & $(1.30)$ & $(1.27)$ \\
\hline \multirow[t]{2}{*}{ Group size (1000s) } & -0.00689 & -0.00256 & -0.00429 \\
\hline & $(-1.09)$ & $(-0.35)$ & $(-0.59)$ \\
\hline \multirow[t]{2}{*}{ Unemployment } & 0.0653 & 0.0342 & 0.0387 \\
\hline & $(1.25)$ & $(0.58)$ & $(0.65)$ \\
\hline \multirow[t]{2}{*}{ Austria } & & 0.983 & \\
\hline & & $(0.80)$ & \\
\hline \multirow[t]{2}{*}{ France } & & 1.028 & \\
\hline & & $(1.01)$ & \\
\hline \multirow[t]{2}{*}{ Germany } & & -1.199 & \\
\hline & & $(-0.65)$ & \\
\hline \multirow[t]{2}{*}{ Netherlands } & & $3.869^{*}$ & \\
\hline & & $(2.57)$ & \\
\hline \multirow[t]{2}{*}{ Spain } & & 2.128 & \\
\hline & & $(1.46)$ & \\
\hline \multirow[t]{2}{*}{ Switzerland } & & $2.831^{* *}$ & \\
\hline & & $(2.61)$ & \\
\hline \multirow[t]{2}{*}{ Collective rights } & & & $-1.912^{*}$ \\
\hline & & & $(-2.01)$ \\
\hline \multirow[t]{2}{*}{ Individual rights } & & & -0.940 \\
\hline & & & $(-0.77)$ \\
\hline \multirow[t]{2}{*}{ Constant } & $-5.482^{* * *}$ & $-6.042^{* * *}$ & $-4.814^{* * *}$ \\
\hline & $(-4.67)$ & $(-4.49)$ & $(-3.86)$ \\
\hline N & 288 & 288 & 273 \\
\hline $\mathrm{AIC}$ & 148.9 & 145.1 & 136.1 \\
\hline $\mathrm{BIC}$ & 178.2 & 196.4 & 172.2 \\
\hline
\end{tabular}

t-statistics in brackets; ${ }^{*} p<0.05,{ }^{* *} p<0.01,{ }^{* * *} p<0.001$.

which the coefficient did appear to be insignificant, which suggests that the statistical relationship shown in the other models is spurious.

Also, the relationship between the share of immigrants occupied in industry and migrant protest is in line with the previous analysis: if at all, ethnic division of labor only explains variation at the country level. Regarding the fact that it does not predict migrant protest across time nor between groups within the same country in a significant way, the relationship must be considered inexistent or rather weak. Also, group size 
and the share of migrant members in unemployment is not significantly related to the propensity to protest.

Finally, the availability of collective group rights of migrants in the receiving country is now negatively correlated with migrant protest. This relationship goes into the opposite direction from what we would typically expect from political opportunity structure theory. Furthermore, as the subsequent analysis will show the relationship reveals to be unstable. Also, the individual rights for immigrants in the countries are not significantly related to migrant protest.

Table 5 Logistic regression for presence of migrant protest at the group level

\begin{tabular}{|c|c|c|c|}
\hline & Model 1 & Model 2 & Model 3 \\
\hline \multirow[t]{2}{*}{ Autocracy or ethnic war } & $1.292^{*}$ & $1.241+$ & $1.504^{*}$ \\
\hline & $(2.05)$ & $(1.92)$ & $(2.13)$ \\
\hline \multirow[t]{2}{*}{ Share Muslims } & $1.198^{*}$ & $1.284^{*}$ & $1.249^{*}$ \\
\hline & $(2.28)$ & $(2.33)$ & $(2.27)$ \\
\hline \multirow[t]{2}{*}{ Share linguistically distinct } & -0.741 & -0.224 & -0.279 \\
\hline & $(-1.16)$ & $(-0.33)$ & $(-0.38)$ \\
\hline \multirow[t]{2}{*}{ Share postcolonial migrants } & -0.800 & -0.175 & -0.784 \\
\hline & $(-1.06)$ & $(-0.21)$ & $(-0.89)$ \\
\hline \multirow[t]{2}{*}{ Share foreigners in industry (rel.) } & $6.129^{*}$ & $5.626+$ & $5.505+$ \\
\hline & $(2.39)$ & $(1.81)$ & $(1.84)$ \\
\hline \multirow[t]{2}{*}{ Group size (1000s) } & -0.00353 & -0.00181 & -0.00125 \\
\hline & $(-0.63)$ & $(-0.30)$ & $(-0.21)$ \\
\hline \multirow[t]{2}{*}{ Unemployment } & 0.0467 & 0.0332 & 0.0251 \\
\hline & $(0.98)$ & $(0.67)$ & $(0.50)$ \\
\hline \multirow[t]{2}{*}{ Austria } & & -0.00545 & \\
\hline & & $(-0.01)$ & \\
\hline \multirow[t]{2}{*}{ France } & & 0.241 & \\
\hline & & $(0.28)$ & \\
\hline \multirow[t]{2}{*}{ Germany } & & 0.381 & \\
\hline & & $(0.24)$ & \\
\hline \multirow[t]{2}{*}{ Netherlands } & & $2.560+$ & \\
\hline & & $(1.81)$ & \\
\hline \multirow[t]{2}{*}{ Spain } & & 0.798 & \\
\hline & & $(0.65)$ & \\
\hline \multirow[t]{2}{*}{ Switzerland } & & $1.523+$ & \\
\hline & & $(1.83)$ & \\
\hline \multirow[t]{2}{*}{ Collective rights } & & & -1.326 \\
\hline & & & $(-1.51)$ \\
\hline \multirow[t]{2}{*}{ Individual rights } & & & -0.232 \\
\hline & & & $(-0.21)$ \\
\hline \multirow[t]{2}{*}{ Constant } & $-5.842^{* * *}$ & $-5.853^{* * *}$ & $-5.584^{* * *}$ \\
\hline & $(-4.88)$ & $(-4.67)$ & $(-4.27)$ \\
\hline $\mathrm{N}$ & 288 & 288 & 273 \\
\hline AlC & 150.0 & 153.7 & 140.1 \\
\hline $\mathrm{BIC}$ & 179.3 & 205.0 & 176.2 \\
\hline
\end{tabular}

t-statistics in brackets; $+p<0.1,{ }^{*} p<0.05,{ }^{* *} p<0.01,{ }^{* * *} p<0.001$. 
In Table 5 we replicate the analysis with our alternative measure for war or discrimination in the sending state (see above). Again, we find a positive and significant relationship in all models. This means that migrants from autocratic regimes or ethnic wars engage more in protest than other migrants. The levels of significance are lower if we make use of this indicator instead of the indicator measuring the number of asylum seekers per group. We attribute these lower levels of significance to the inferior quality of this alternative measure. ${ }^{13}$ Overall, however, the result that migrant protest is largely determined by transnational relations is very robust.

Also, we do find very similar coefficients for all other variables. The only partial exception is the result that the relationship between collective groups rights and migrant protest is no longer significant. The latter result together with those from the timeseries analysis indicates that political opportunity structures do not play an important role in structuring migrant protest.

\section{Conclusion}

This article has tried to shed new light on the determinants of the political mobilization of migrants. It has first critically discussed the dominant theory of the political behavior of migrants and pointed to alternative explanations to the topic. In particular, we argued that in order to analyze migrant protest, one has to go beyond the institutional logic of the POS approach. As alternatives we have proposed to test theories that emphasize societal factors and the political logic of alliance formation. Applied to migrant protest, the argument in particular was that cultural distance and ethnic division of labor can be expected to trigger migrant protest. Relying on transnationalist theory, we also hypothesized that war or discrimination in the sending state is a precondition for migrant mobilization.

By making use of protest event data, we were able to describe levels and trends in migrant protest in seven countries as well as test hypotheses with a large sample size at the macro-level. The results of the empirical analysis suggest that political opportunity structures are of little relevance to the protest mobilization of migrants. Instead, the results lend more support to transnationalist theory. Why has this article come to this surprising result? One reason could be that the empirical evidence related to the relationship of narrow POS with the mobilization of migrants heavily relies on the analysis of claimsmaking. Also, these analyses mostly rely on cross-sectional analysis which might have caused an overestimation of cross-country variance and a neglect of variance over time.

This article complements research that focuses more narrowly on the micro-level or the quality of the claims made by the migrants when politically active. The findings from the time-series analysis at the country-level and the cross-sectional analysis at the group level are, however, not perfectly compatible. The reason is that historical data had to be aggregated at the national level and that lack of valid historical data made the use of crude proxies inevitable. Hence, in order to reconcile competing findings between the two analyses, future research will have to produce valid historical data and analyze ethnic protest at the group level over time.

\section{Endnotes}

${ }^{1}$ This is also true because they might suffer from severe overestimation of political participation, a phenomenon well known in the study of voter turnout. 
${ }^{2}$ In this respect this approach resembles many of Rokkan's writings (Rokkan, 1999). Rokkan conceptualized formal institutions on the same level of causality as societal variables by summarizing them as economic, cultural, and administrative (sometimes also military) boundaries.

${ }^{3}$ Classical references for discussions of new institutionalism are Skocpol, (1985); March and Olsen, (1989); Powell and Di Maggio, (1991); Hall and Taylor, (1996).

${ }^{4}$ Cultural distance according to this understanding should not be confused with distance in regard to cultural capital, as Bourdieu, (1990) saw it. With his concept of cultural capital, Bourdieu focused on distance within the same system, while our intention is to focus on distance between systems. According to Bourdieu, symbol systems between cultures are completely different.

${ }^{5}$ Here only the problems of the data relevant for this article and propositions for its avoidance are discussed. For an extensive discussion of strengths and weaknesses of protest event data, readers should refer to the work of Hutter, (2011).

${ }^{6}$ This is, in contrast to what might be expected, not necessary for the French data. As Le Monde had a different deadline than the other newspapers, it was expected that it would miss Sunday events and this way create selection bias (Fillieule, 1996, p. 21). As Hutter, (2011, pp. 136-137) demonstrates, the bias, however, is small and neither impacts on his own analysis nor that of Kriesi et al., (1995).

${ }^{7}$ For Switzerland only between 2000 and 2005.

${ }^{8}$ Kettani, (1986) used a more narrow definition of being Muslim than Savage, (2004) that is more in line with the definition by the Pew Research Centre.

${ }^{9}$ For Germany data was only available on the share of foreign workers in the manufacturing industry.

${ }^{10}$ Since the analysis is conducted at the national group level, ethnic groups had to be assigned to their sending state. Problems of description bias might challenge the analysis of the protest of migrant minorities at the group level. Description bias results from the interpretations journalists already make while reporting, for instance by using certain categories and abstaining from others. The reason the description bias might be an issue for the analysis at the group level is that some countries might show a stronger tendency to categorize migrants along religious, policy-relevant or racial categories rather than ethnic and national ones. However, while recoding the core sentences, we found only few references to these alternative categories with the that of the "sans-papiers" in France to be most common. The ethnic groups were assigned the following sending states: (Kosovo-)Albanians to Serbia and Montenegro; Berbers to Algeria; Harkis to Algeria; Tibetians to China; Kurds to Turkey; Alouite to Turkey; Maghrebi in Spain to Morocco. The data does not include cases in which no ethnic or national origin was named, neither does it include groups that could be native minorities (e.g. Roma, Sinti or Jews).

${ }^{11}$ This was not possible for the time-series analysis because of lacking data on the group sizes and resulting problems of aggregation.

${ }^{12} \mathrm{~A}$ good example for a state being considered as rather democratic, but where ethnic minorities are discriminated against is Turkey. The minimal Polity IV score for the time period was taken because it can be assumed that most migrants were motivated at these points in time to migrate and/or to engage in protest. Data has been available for all cases except for the Netherlands Antilles and Suriname. We coded the Netherlands Antilles as a democracy and Suriname as an autocracy. 
${ }^{13}$ We believe this alternative indicator to be of inferior quality because it aggregates at the group level, while the number of asylum seekers per migrant group accounts for variance within the group.

\section{Competing interests}

The authors declare that they have no competing interests.

Received: 6 December 2013 Accepted: 24 October 2014

Published online: 21 May 2015

\section{References}

Alesina, A, \& Giuliano, P. (2011). Family Ties and Political Participation. Journal of the European Economic Association, 9(5), 817-39. doi:10.1111/j.1542-4774.2011.01024.x.

Barranco, J, \& Wisler, D. (1999). Validity and Systematicity of Newspaper Data in Event Analysis. European Sociological Review, 15(3), 301-22.

Barreto, MA. (2007). Sí Se Puede! Latino Candidates and the Mobilization of Latino Voters. American Political Science Review, 101(03), 425-41.

Bird, K, Saalfeld, T, \& Wüst, A. (2011). Ethnic Diversity, Political Participation, and Representation: A Theoretical Framework. In The Political Representation of Immigrants and Minorities: Voters, Parties and Parliaments in Liberal Democracies, edited by Bird, K., Saalfeld, T. \& Wüst, A. 1-22 London: Routledge.

Bjørnskov, C, \& Sønderskov, K. (2010). SSRN Scholarly Paper ID 1593507. In Is Social Capital a Good Concept? Rochester, NY: Social Science Research Network. http://papers.ssrn.com/abstract=1593507.

Boix, C, \& Stokes, S. (2003). Endogenous Democratization. World Politics, 55(4), 517-49.

Bourdieu, P. (1990). The Logic of Practice. Stanford: Stanford University Press.

Brown, M. (2000). Quantifying the Muslim Population in Europe: Conceptual and Data Issues. International Journal of Social Research Methodology, 3(2), 87-101. doi:10.1080/136455700405163.

Castles, S. (2002). Migration and Community Formation under Conditions of Globalization. International Migration Review, 36(4), 1143-68.

Cederman, LE, Wimmer, A, \& Min, B. (2010). Why Do Ethnic Groups Rebel?: New Data and Analysis. World Politics, 62(1), 87-119.

Cinalli, M, \& Giugni, M. (2013). Political Opportunities, Citizenship Models and Political Claim-Making over Islam. Ethnicities, 13(2), 147-64. doi:10.1177/1468796812470896.

Connor, W. (1994). Eco- or Ethno-Nationalism? In Ethnonationalism: The Quest for Understanding, edited by Connor, W., 146-64. Princeton Princeton University Press.

Ebert, K, \& Okamoto, D. (2013). Social Citizenship, Integration and Collective Action: Immigrant Civic Engagement in the United States. Social Forces, 91(4), 1267-92. doi:10.1093/sf/sot009.

Eggert, N, \& Giugni, M. (2010). Does Associational Involvement Spur Political Integration? Political Interest and Participation of Three Immigrant Groups in Zurich. Swiss Political Science Review, 16(2), 175-210.

Fennema, M, \& Tillie, J. (1999). Political Participation and Political Trust in a Multicultural Democracy. Civic Communities and Ethnic Networks in Amsterdam. Journal of Ethnic and Migration Studies, 25(4), 703-26.

Fennema, M, \& Tillie, J. (2001). Civic Community, Political Participation and Political Trust of Ethnic Groups. Connections, 24(1), 26-41.

Fillieule, O. (1996). Police Records and the National Press in France. Issues in the Methodology of Data-Collections from Newspapers. In RSCAS Working Papers (p. 25).

Giugni, M, \& Passy, F. (2004). Migrant Mobilization between Political Institutions and Citizenship Regimes: A Comparison of France and Switzerland. European Journal of Political Research, 43(1), 51-82.

Grim, B, \& Karim, M. (2011). The Future of the Global Muslim Population: Projections for 2010-2030. Pew Research Center. http://pewforum.org/The-Future-of-the-Global-Muslim-Population.aspx.

Hall, P, \& Taylor, R. (1996). Political Science and the Three New Institutionalisms. Political Studies, 44(5), 936-57. doi:10.1111/j.1467-9248.1996.tb00343.x.

Hechter, M, \& Levi, M. (1979). The Comparative Analysis of Ethnoregional Movements. Ethnic and Racial Studies, 2(3), 260-74

Hocke, P. (2002). Massenmedien und lokaler Protest: eine empirische Fallstudie zur Medienselektivität in einer westdeutschen Bewegungshochburg [Mass Media and Local Protest: an Empirical Case Study on the Selectivity of the Media in a West German Social Movement Stronghold]. Wiesbaden: Westdeutscher Verlag.

Hooghe, M. (2005). Ethnic Organisations and Social Movement Theory: The Political Opportunity Structure for Ethnic Mobilisation in Flanders. Journal of Ethnic and Migration Studies, 31(5), 975-90.

Hug, S. (2003). Selection Bias in Comparative Research: The Case of Incomplete Data Sets. Political Analysis, 11(3), 255-74.

Hug, S, \& Wisler, D. (1998). Correcting for Selection Bias in Social Movement Research. Mobilization: An International Quarterly, 3(2), 141-61.

Hutter, S. (2011). Protest Politics and the Right Populist Turn: A Comparative Study of Six West European Countries, 1975-2005. Ludwig-Maximilians-Universität München: Unpublished Manuscript.

Hutter, S, \& Giugni, M. (2009). Protest Politics in a Changing Political Context: Switzerland, 1975-2005. Swiss Political Science Review, 15(3), 427-61.

Ireland, P. (1994). The Policy Challenge of Ethnic Diversity. Immigrant Politics in France and Switzenland. Cambridge, MA: Harvard University Press.

Jacobs, D, \& Tillie, J. (2004). Introduction: Social Capital and Political Integration of Migrants. Journal of Ethnic and Migration Studies, 30(3), 419-27. doi:10.1080/13691830410001682016.

Jacobs, D, Phalet, K, \& Swyngedouw, M. (2006). Political Participation and Associational Life of Turkish Residents in the Capital of Europe. Turkish Studies, 7(1), 145-61. doi:10.1080/14683840500520659. 
Jacobs, D, Swyngedouw, M, Hanquinet, L, Vandezande, V, Andersson, R, Horta, A, \& Statham, P. (2009). The Challenge of Measuring Immigrant Origin and Immigration-Related Ethnicity in Europe. Journal of International Migration and Integration, 10, 67-88. doi:10.1007/s12134-009-0091-2.

Kettani, MA. (1986). Muslim Minorities in the World Today. London: Mansell.

Klandermans, B, Van der Toorn, J, \& Van Stekelenburg, J. (2008). Embeddedness and Identity: How Immigrants Turn Grievances into Action. American Sociological Review, 73(6), 992-1012. doi:10.1177/000312240807300606.

Koopmans, R. (1995). Appendix: The Newspaper Data. In New Social Movements in Western Europe: A Comparative Analysis, edited by Kriesi, H, Koopmans, R., Duyvendak, J.W. Giugni, M. 253-73. Minneapolis: University of Minnesota Press.

Koopmans, R. (2004). Migrant Mobilisation and Political Opportunities: Variation among German Cities and a Comparison with the United Kingdom and the Netherlands. Journal of Ethnic and Migration Studies, 30(3), 449-70.

Koopmans, R, Passy, F, Statham, P, \& Giugni, M. (2005). Contested Citizenship: Immigration and Cultural Diversity in Europe. Minneapolis: University of Minnesota Press.

Koopmans, R, Michalowski, I, \& Waibel, S. (2012). Citizenship Rights for Immigrants: National Political Processes and Cross-National Convergence in Western Europe, 1980-2008. AJS; American Journal of Sociology, 117(4), 1202-45.

Kriesi, H, Koopmans, R, Duyvendak, JW, \& Giugni, M (Eds.). (1995). New Social Movements in Western Europe: A Comparative Analysis. Minneapolis: University of Minnesota Press.

Licht, AN, Goldschmidt, C, \& Schwartz, H. (2007). Culture Rules: The Foundations of the Rule of Law and Other Norms of Governance. Journal of Comparative Economics, 35(4), 659-88. doi:10.1016/j.jce.2007.09.001.

March, J, \& Olsen, J. (1989). Rediscovering Institutions: The Organizational Basis of Politics. New York: Free Press.

Marshall, M, \& Jaggers, K. (2002). Polity IV Project: Political Regime Characteristics and Transitions, 1800-2002; Dataset Users' Manual. College Park 20742: Integrated Network for Societal Conflict Research (INSCR) Program Center for International Development and Conflict Management (CIDCM), University of Maryland. www.cidcm.umd.edu/inscr/polity.

Maxwell, R. (2010). Political Participation in France among Non-European-Origin Migrants: Segregation or Integration? Journal of Ethnic and Migration Studies, 36(3), 425-43. doi:10.1080/13691830903471537.

Maxwell, R. (2012). Ethnic Minority Migrants in Britain and France: Integration Trade-Offs. Cambridge: Cambridge University Press.

Messina, AM. (2007). The Logics and Politics of Post-WWII Migration to Western Europe. Cambridge: Cambridge University Press.

Morales, L, \& Giugni, M (Eds.). (2011). Social Capital, Political Participation and Migration in Europe. Houndmills, Basingstoke: Palgrave.

Mügge, L. (2012). Ethnography's Contribution to Newspaper Analysis: Claims-Making Revisited. In CES Papers - Open Forum 12

Neumayer, E. (2005). Bogus Refugees? The Determinants of Asylum Migration to Western Europe. International Studies Quarterly, 49(3), 389-410. doi:10.1111/j.1468-2478.2005.00370.x.

Norris, P, \& Inglehart, R. (2012). Muslim Integration into Western Cultures: Between Origins and Destinations. Political Studies, 60(2), 228-51. doi:10.1111/j.1467-9248.2012.00951.x.

Olzak, S. (2006). The Global Dynamics of Racial and Ethnic Mobilization. Stanford: Stanford University Press.

Ortiz, D, Myers, D, Walls, E, \& Diaz, ME. (2005). Where Do We Stand with Newspaper Data? Mobilization: An International Quarterly, 10(3), 397-419.

Portes, A, \& Rumbaut, R. (2006). Immigrant America: A Portrait. Berkely and Los Angeles: University of California Press.

Powell, W, \& Di Maggio, P. (1991). The New Institutionalism in Organizational Analysis. Chicago: University of Chicago Press.

Przeworski, A. (1991). Democracy and the Market: Political and Economic Reforms in Eastern Europe and Latin America. Cambridge: Cambridge University Press.

Putnam, R, Leonardi, R, \& Nanetti, R. (1994). Making Democracy Work: Civic Traditions in Modern Italy. Princeton: Princeton University Press.

Rendall, M, \& Salt, J. (2006). The foreign-born population. In Office for National Statistics (Ed.), The focus on people and migration (pp. 131-152). Basingstoke: Palgrave MacMillan.

Rogowski, R, \& MacRae, D. (2004). Inequality and Institutions: What Theory, History, and (Some) Data Tell Us. Chicago: American Political Science Association conference.

Rokkan, S. (1999). State Formation, Nation-Building, and Mass Politics in Europe. In State Formation, Nation-Building, and Mass Politics in Europe: The Theory of Stein Rokkan Based on His Collected Works, edited by Flora, P., Kuhnle, S. \& Urwin, D. Oxford: Oxford University Press.

Safi, M. (2006). Le devenir des immigrés en France. Barrières et inégalités. Dissertation at Ecole des Hautes Etudes en Sciences Sociales.

Savage, T. (2004). Europe and Islam: Crescent Waxing, Cultures Clashing. The Washington Quarterly, 27(3), 25-50. doi:10.1162/016366004323090241.

Schönwälder, K. (2009). Einwanderer Als Wähler, Gewählte und transnationale Akteure [Immigrants as voters, representatives, and transnational actors]. Politische Vierteljahresschrift, 50(4), 832-49. doi:10.1007/s11615-009-0158-X.

Sewell, W, Jr. (1992). A Theory of Structure: Duality, Agency, and Transformation. American Journal of Sociology, 98(1), 1-29.

Skocpol, T. (1985). Bringing the State Back In: Strategies of Analysis In Current Research. In Bringing the State Back In, edited by Evans, P.,Rueschemeyer, D. \& Skocpol, T., 3-37. Cambridge: Cambridge University Press.

Statham, P. (1999). Political Mobilisation by Minorities in Britain: Negative Feedback of 'Race Relations'? Journal of Ethnic and Migration Studies, 25(4), 597-626.

Strijbis, O. (2011). Aktiv, links und herkunftsorientiert: Die politische Partizipation von Migranten aus der Türkei in der Schweiz [Active, left and homeland-oriented: The political participation of immigrants from Turkey in Switzerland]. In M Ideli, V Suter Reich, \& HL Kieser (Eds.), Neue Menschenlandschaften: Migration Türkei-Schweiz (pp. 183-97). Zürich: Chronos.

Strijbis, O. (2014a). Migration Background and Voting Behavior in Switzerland: A Socio-Psychological Explanation. Swiss Political Science Review, 20(4), 612-631. doi:10.1111/spsr.12136.

Strijbis, O. (2014b). From Native to Immigrant Minorities: Ethnic Mobilization in Western Europe since World War I. Unpublished Manuscript. University of St. Gallen.

Teney, C, Jacobs, D, Rea, A, \& Delwit, P. (2010). Ethnic Voting in Brussels: Voting Patterns Among Ethnic Minorities in Brussels (Belgium) During the 2006 Local Elections. Acta Politica, 45, 273-97. doi:10.1057/ap.2009.25. 
Ticchi, D, \& Vindigni, A. (2003). Endogenous Constitutions. In Institute for International Economic Studies, Stockholm University Seminar Paper (p. 726).

Van Londen, M, Phalet, K, \& Hagendoorn, L. (2007). Civic Engagement and Voter Participation among Turkish and Moroccan Minorities in Rotterdam. Journal of Ethnic and Migration Studies, 33(8), 1201-26. doi:10.1080/13691830701613991.

Wimmer, A. (2002). Nationalist Exclusion and Ethnic Conflict: Shadows of Modernity. Cambridge: Cambridge University Press.

Submit your manuscript to a SpringerOpen ${ }^{\circ}$ journal and benefit from:

- Convenient online submission

- Rigorous peer review

- Immediate publication on acceptance

- Open access: articles freely available online

- High visibility within the field

- Retaining the copyright to your article

Submit your next manuscript at $>$ springeropen.com 